\title{
ANCHETA DIALECTALĂ DIN SCĂRIȘOARA (ALR II). MODALITĂȚI DE VALORIFICARE A TEXTULUI DIALECTAL*
}

\section{Introducere}

Ancheta dialectală din Scărișoara pentru Atlasul lingvistic român II a fost realizată de Emil Petrovici în anii 1935 și 1937. Pe lângă documentarea lingvistică și adunarea de material dialectal în cadrul proiectului ALR II, această anchetă a fost destinată şi culegerii de material folcloric (vezi ALR II. Introducere, p. 45).

Zona Scărişoarei a prezentat interes din partea lingviștilor şi etnografilor cu mult înainte de această perioadă ${ }^{1}$. Modul de viață al locuitorilor, care trăiau în crânguri izolate, situate la distanță de centrele comunale, contactul redus al locuitorilor cu factorii instituționalizării și culturalizării au determinat conservarea unor fenomene fonetice specifice (rotacismul) și morfosintactice, cu o răspândire restrânsă. Punctul de anchetă 95 Scărișoara din rețeaua ALR II desemnează, de fapt, două regiuni: zona Ghețarului ${ }^{2}$ (crângul Pășcești) și Valea de la Iarba Rea (crângurile Morărești, Pleitești). Imaginea lingvistică a zonei istorice a moților este întregită de informațiile din punctele de anchetă ale ALR I investigate de Sever Pop (pct. 93 Arieșeni, pct. 94 Avram Iancu și pct. 96 Certege).

Pentru realizarea anchetei, E. Petrovici a apelat la 13 informatori, respectând principiul variației diatopice și diastratice; dintre aceștia, șase au fost respondenți la Chestionarul ALR II, iar de la ceilalţi șapte informatori s-au cules numai texte (vezi ALR II. Introducere, p. 47-49).

Ca și în cazul celorlalte puncte cartografice din rețeaua ALR II, și caietul care cuprinde anchetele din Scărișoara se păstrează în arhiva atlasului, fiind vorba atât de materialul pe care Emil Petrovici l-a publicat în „Anuarul Arhivei de Folklor”, 1939, p. 111-175, sub titlul Folklor la moții din Scărişoara, cât și de ancheta dialectală propriu-zisă. De altfel, nu poate fi făcută o departajare între ancheta dialectală și ancheta folclorică, materialul folcloric fiind parte a anchetei lingvistice. În manuscrisul acestor documente Emil Petrovici face o singură distincție între

\footnotetext{
* Această lucrare a fost elaborată în cadrul Grantului de cercetare realizat cu sprijin financiar din Fondul Recurent al Donatorilor, aflat la dispoziţia Academiei Române şi gestionat prin Fundaţia „PATRIMONIU” GAR-UM-2019-I-1.6-4: „Accesibilizarea fondului documentar ALRT II (ACCES -ALRT II) ", Contract numărul 364C din 15.10.2019.

1 Amintim aici doar două dintre cele mai cunoscute studii: Frâncu, Candrea 1888, Papahagi $1925-1926$.

${ }^{2}$ Din punct de vedere administrativ, astăzi zona Ghețarului aparține de localitatea Gârda de Sus.
} 
materialul dialectal și materialul folcloric, în categoria de texte (vezi infra, 1.3.), caietul având un mod de organizare similar celor din alte puncte de anchetă din rețeaua ALR II (secțiunile: I. Subiecții anchetați și chestiunile documentate cu fiecare subiect, data anchetelor; II. Jurnalul anchetei și notele fonetice; III. Diverse; IV. Texte; V. Ancheta propriu-zisă).

Observațiile lui Emil Petrovici legate de ancheta din Scărișoara au fost valorificate în două variante: într-o variantă mai extinsă, în AAF (vezi Petrovici 1939), și, într-o formă restrânsă, acest material poate fi regăsit în ALR II. Introducere (p. 44-54).

În cele ce urmează, ne vom referi la secțiunea de texte ${ }^{3}$ din caietul de anchetă, respectiv: 1) categoriile de texte identificate, după suportul material și tematică, în corelație cu informațiile din jurnalul de anchetă; 2) modalitățile de valorificare a acestui material, prin compararea manuscrisului cu textele publicate (având în vedere atât materialul publicat în AAF V, cât și cel publicat în ALRT II) şi 3) perspectiva (re)valorificării unitare și integrale a textelor din punctul 95 Scărișoara.

\section{Categoriile de documente aflate caietul de anchetă din arhivă}

După tipul de file utilizate pentru transcriere, numerotarea pe secțiuni a acestora și organizarea lor în funcție de datele din jurnalul de anchetă am identificat următoarele cinci categorii:

1.1.Paginile numerotate 101-194, dintre acestea unele reprezentând filele originale, în creion, altele copia cu indigo ${ }^{4}$. Sunt notate pe filele caietului de anchetă ALR II (vezi infra, 1.1. Foto ms. 108, 137);

1.2. Un set de texte notate pe file dictando, numerotate de la 1 la 59 , dintre acestea, primele 5 file fiind decupate și lipite pe alte file, unele redactate (cu cerneală neagră peste creion), altele păstrate cu transcrierea originală (vezi infra, 1.2. Foto ms. 1, 14)

1.3. Texte notate cu cerneală neagră, pe fișe de dimensiuni mai reduse (numerotate, inițial de la 18 la 39, apoi corectate, de la 25 la 46), cu notația pretipărită NOTE. Pe acestea sunt texte culese în Iarba Rea și Gârda de Sus/Morărești, Pleitești cu mențiunea „Folklor”, sâmbătă, 27. VIII. 1935 și aparțin informatorilor dávid tódor moraréscu, fluríia ńégri ionásás, rah'ila ńégrea. Textele sunt redactate utilizându-se creion roșu pentru delimitare și/sau marcarea paragrafelor (vezi infra, 1.3. Foto ms. 29, 31, 40, 41).

\footnotetext{
${ }^{3}$ Observațiile referitoare la celelalte secțiuni ale materialelor din această anchetă sunt valorificate sub forma unui studiu ce va fi publicat de noi în 2022.

${ }^{4}$ Filele originale au fost utilizate pentru redactarea textelor direct pe acestea, prin intervenția cu cerneală și creion roșu peste textul transcris inițial. A se vedea, de exemplu, manuscrisul textelor redactate pentru publicate în ALRT II (1.5. Foto ms. 1, 110 (19)).
} 

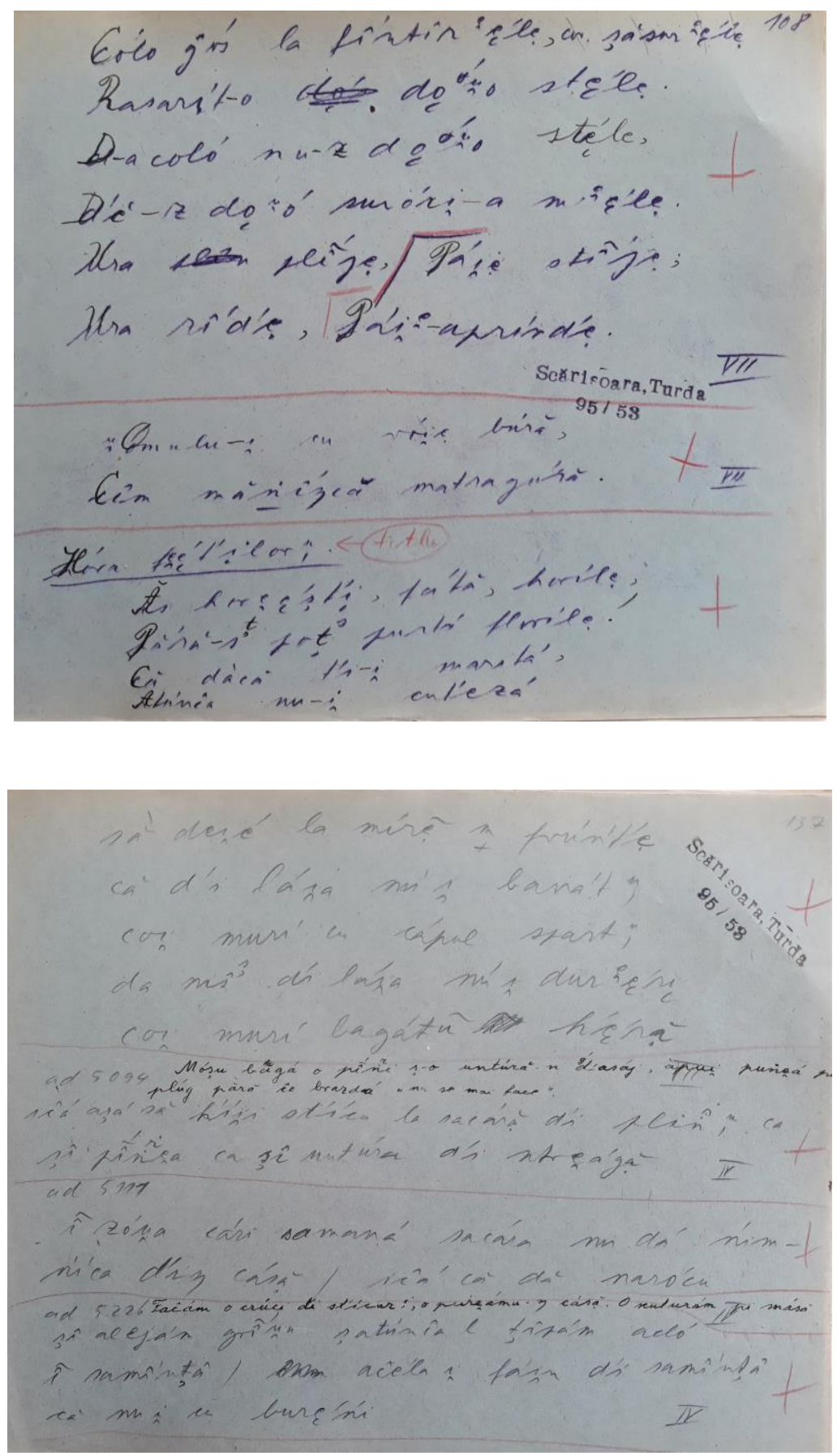

1.1. Foto ms., filele 10 și 137 din secțiunea de texte 

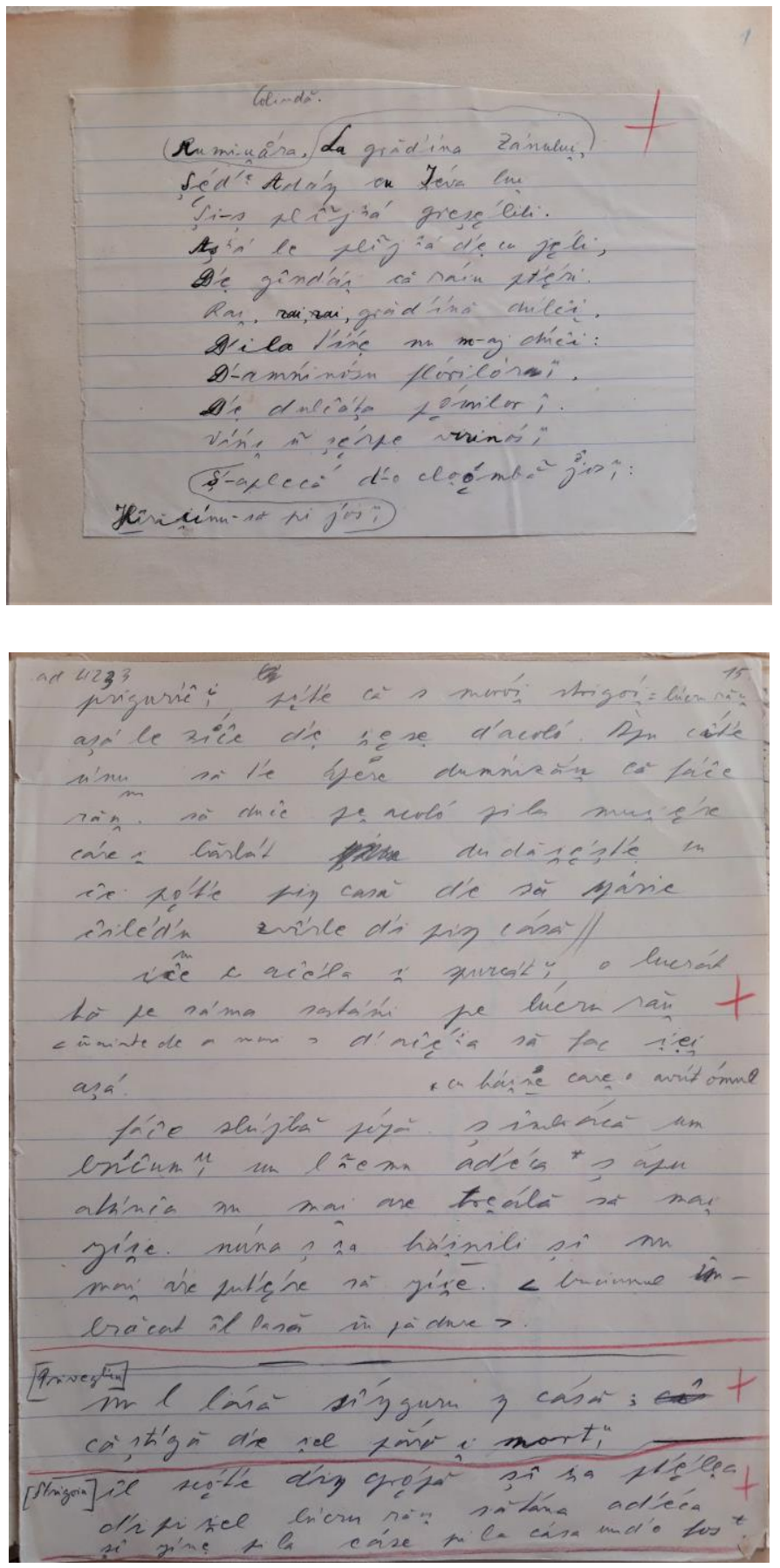

1.2. Foto ms., filele 1,15 din secțiunea de texte 

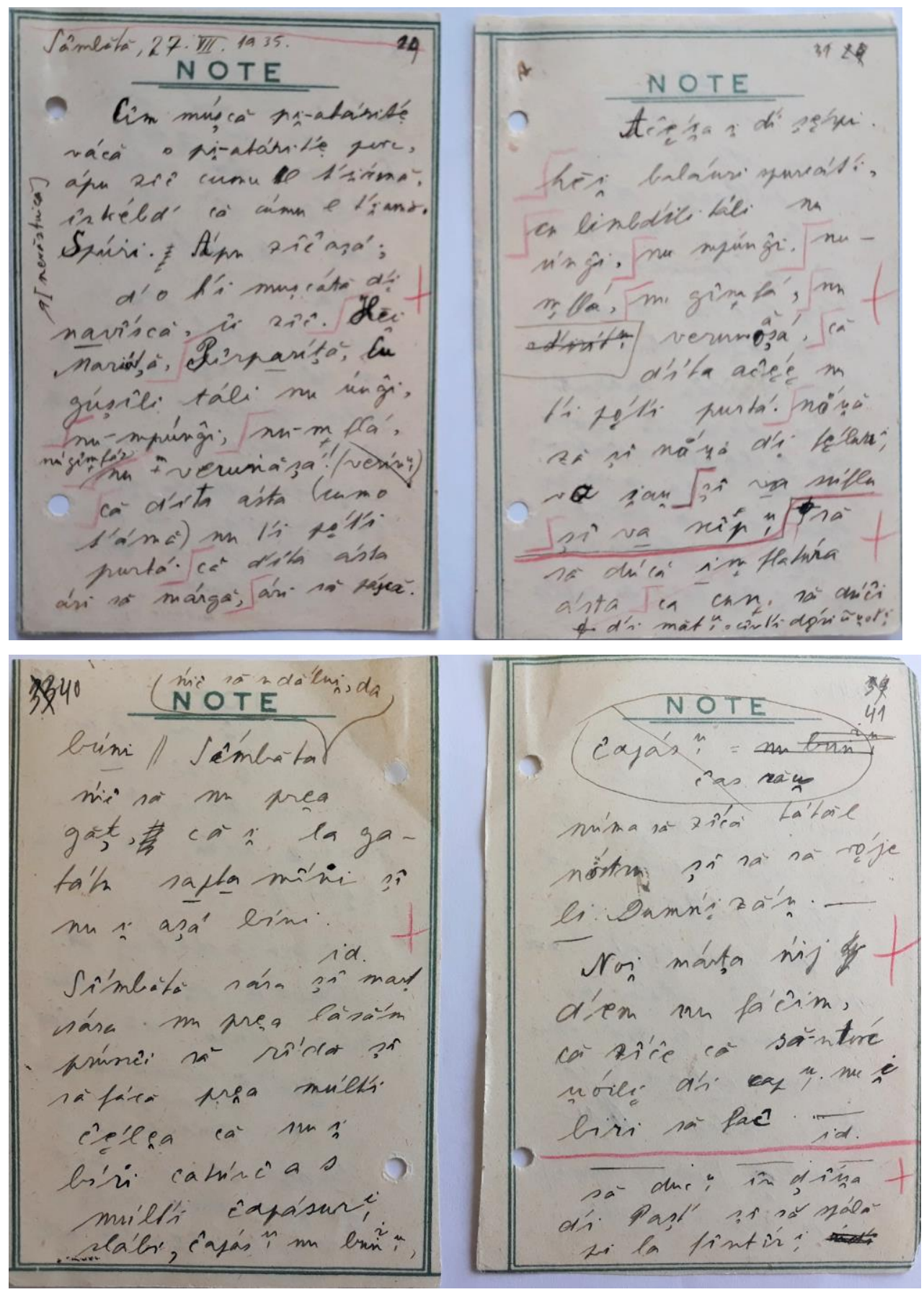

1.3. Foto ms., filele 29, 31, 40, 41 din secțiunea de texte 
1.4. Un set de file dictando și veline, nenumerotate (23 la număr), pe care sunt extrase informațiile notate pentru chestiuni din cuprinsul anchetei pentru ALR II. Acestea sunt publicate în AAF V la secțiunea Obiceiurile. La sărbători, La naştere, La nuntă, La moarte și înmormântare (Petrovici 1939, p. 125-132).

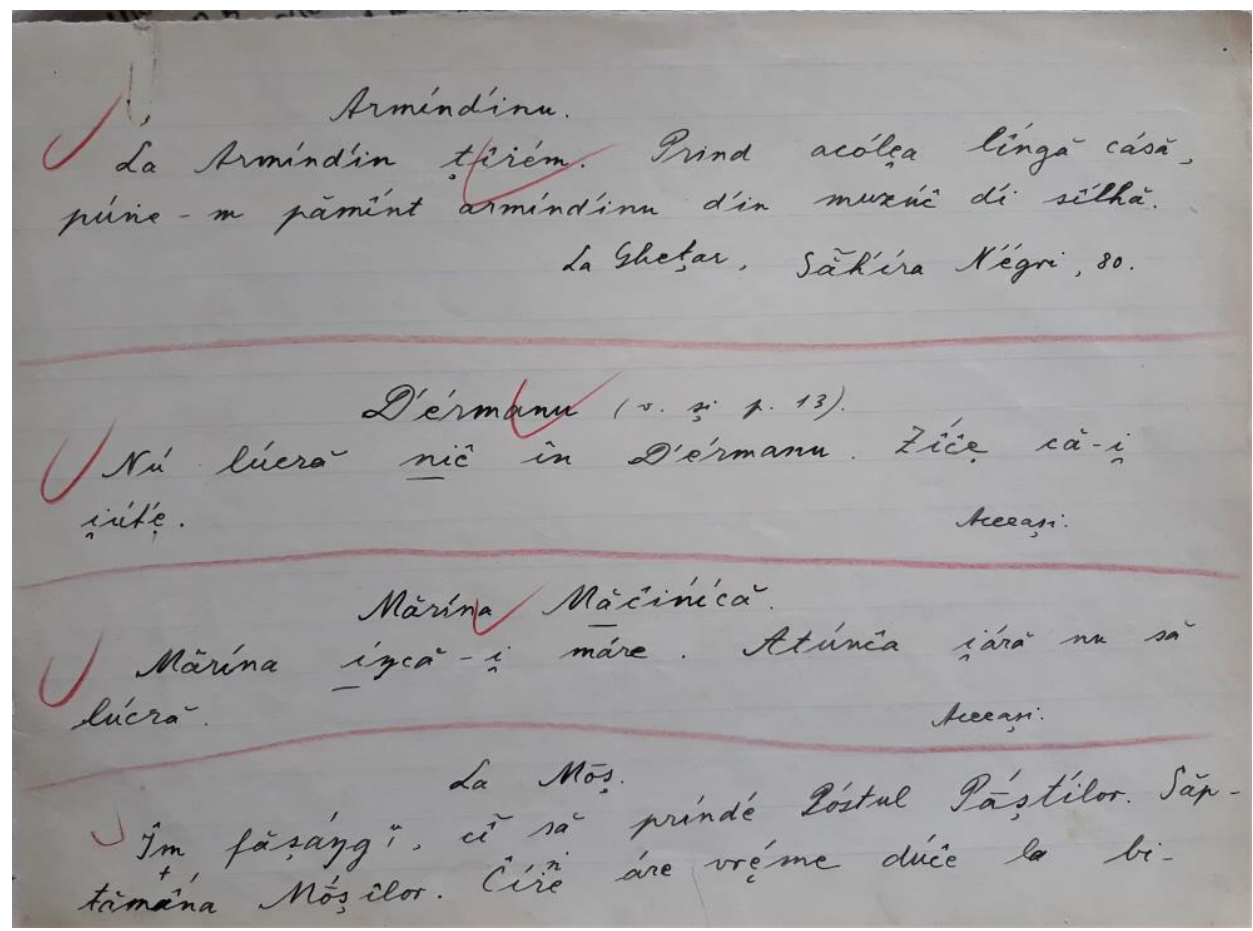

1.4. Foto ms. Obiceiuri de Arminden etc.

1.5. Textele redactate pentru publicare în ALRT II, 45 de file. Acestea sunt reprezentate de texte transcrise cu cerneală sau la maşina de scris (cu semnele specifice transcrierii fonetice adăugate cu cerneală neagră), pe file veline, file dictando sau file din caietul de anchetă ALR II (ms 1-15). Filele din caietul de anchetă ALR II sunt cele notate în creion și sunt redactate cu cerneală și creion roșu peste creionul grafic (ms. 16-45, peste numerotarea inițială a filelor: 107-124 (16-33); 160-163 (34-37), 127 (39), 130 (40), 129 (41), 170 (42), 185 (43), 179 (45). În acest calup, doar filele 38 și 44 sunt transcrise în cerneală neagră)). Corecturi și completări sunt făcute și cu creion verde (vezi infra, 1.5. Foto ms. 1, 110 (19)).

Pe acestea le găsim publicate în ALRT II (p. 48-64), însă majoritatea au fost cuprinse și în AAF, vezi infra, 2.2.). 

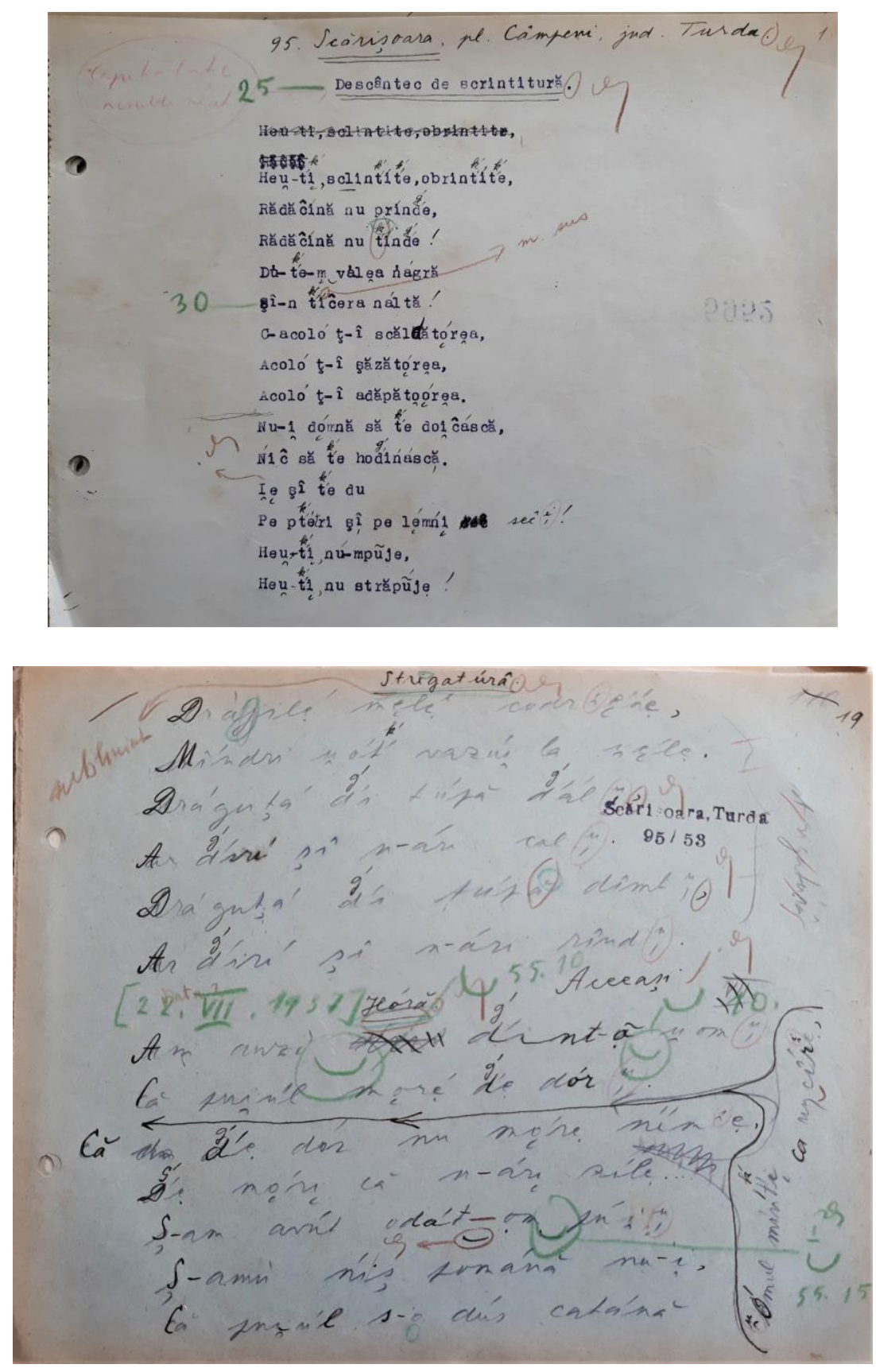

1.5. Foto ms., filele 1,110 (19) din secțiunea de texte 


\section{Modalități de valorificare a textelor culese}

2.1. Din punct de vedere cronologic, primele texte publicate sunt cele redactate de către E. Petrovici pentru AAF, publicate în nr. V din 1939 sub titlul Folklor de la moții din Scărișoara, p. 111-1755.

Arhiva Atlasului lingvistic român păstrează integral textele publicate în anuarul folcloric (precum și textele publicate în ALRT II). Acestea au fost notate pe tipurile de fișe menționate mai sus.

Din punct de vedere tematic și având în vedere numerotarea inițială a fișelor, textele abordează diferite subiecte, asupra cărora se revine după un număr de file, chiar și în cazul aceluiași informator.

Temele folclorice decelate de E. Petrovici pentru textele din anuar sunt următoarele ${ }^{6}$ : „Hori” (doine), Strigături, Colinde, Povești, legende, snoave, Ghicitori, Bocete, Descântece, Practici magice, Diferite credințe și superstiții, Demoni, ființe fantastice sau cu puteri supranaturale, Despre păstorit și viața din trecut. Diverse.

Din punct de vedere cantitativ, între categoriile de texte folclorice menționate se remarcă doar Horile (doinele) (textele numerotate de la 1 la 96) și Strigăturile (textele numerotate de la 97 la 143), notate într-un număr mare. Celelalte tipuri de texte sunt comparabile cantitativ cu textele înregistrate în cadrul anchetei pentru ALR II (vezi ALRT II, secțiunea Indice folkloric, p. 341-351), în care sunt prezente toate categoriile tematice menționate mai sus, inclusiv doinele și strigăturile.

Recurența tematică în aproape toate punctele de anchetă ale atlasului în care au fost înregistrate texte dialectale se explică prin însăși structura și tematica Chestionarului ALR II. O bună cunoaștere și înțelegere a Chestionarului ALR II poate oferi perspectiva corectă asupra anchetei etnofolclorice adiacente atlasului, în integralitatea ei.

Astfel, Chestionarul ALR II cuprinde anumite capitole dedicate integral documentării lingvistice a diferitelor obiceiuri ocazionate de marile sărbători religioase, de diferite sărbători și zile oprite de peste an, de ceremoniile nașterii, ale botezului, ale înmormântării - religioase și/sau împletite cu cele venind din sfera unor superstiții sau credințe străvechi (vezi, de exemplu, capitolele Magie, credințe deșarte, chestiunile 4 226-4 251, Obiceiuri, credințe, chestiunile 5 790-5 800; vezi Vlasin 2021).

Din acest punct de vedere, ancheta din punctul 95 Scărișoara se remarcă doar prin numărul relativ mare de texte aparținând celor două categorii de texte folclorice amintite (hori, strigături).

Astfel, pentru secțiunea Descântece, Chestionarul ALR II documentează chestiuni precum: Cum se apără contra deochiului 4 226, Descântă 4 227, Vrajă 4228 , A fermeca 4 229. La Povești, legende, snoave, textul 147 este, de fapt, aşa cum reiese din manuscris, un text adiacent chestiunii 4246 Cenușăreasa; Ghicitorile apar ca întrebare în Chestionarul ALR II la poziția 4248 Cine-cinel (începutul ghicitorii) $^{7}$ și 4341 Ghicitoare. Secțiunea Practicilor magice, reprezentată de modalități

\footnotetext{
${ }^{5}$ Studiul introductiv, textele, glosarul și fotografiile au fost republicate de Cuceu, Cuceu 2012, p. $9-122$

${ }^{6}$ Vezi E. Petrovici 1939, p. 134.

${ }^{7}$ Vezi formularea Ciumel-ciumel, înregistrată la informatoarele IV şi VII.
} 
de apărare contra deochiului (textul 201 din AAF V), credințe despre salamandră (textul 203 din AAF V), vrăji de dragoste (textele 204, 205 din AAF V), cum se caută un loc bun de casă, ce se pune la temelia unei case sau cum se marchează încheierea construcției (textul 206 din AAF V) sunt chestiuni din Chestionarul ALR II: 4226 Cum se apără contra deochiului, 6232 //salamandră//; ce se crede despre salamandră (când trece peste mână)?, 5798 Ce vrăji se cunosc pentru a aduce pe iubitul sau iubita?, 5800 Ce se pune în temelia casei ca să fie isprăvită cu bine (bani, candelă, umbra unui om etc.)?

Textele încadrate la Diferite credințe și superstiții reprezintă, de multe ori, răspunsuri adiacente pentru diferite chestiuni: 2464 Ce constelaţii cunoşti? [Calea Lactee] - vezi textul 210 Paiele Tiganului din AAF V; Textul 211 Crucea de spice de la secerat din AAF V reprezintă chestiunea 5226 Obiceiuri la secerat și răspunsul adiacent acesteia; textul 212 Obicei la semănat din AAF V reprezintă chestiunea 5094 Care sunt obiceiurile la pornitul plugului? și răspunsul adiacent acesteia sau 5111 Obiceiuri la semănat pentru textul 213 din AAF V etc.

Și credințele sau superstițiile despre diferite animale (corbul, iarba fiarelor, pitpalacul - textele 218-220 din AAF V) apar cu indicaţia ad pe fișa din manuscris: 6165 corb, pl., voc.; 6260 iarba-fiarelor. Ce se ştie despre ea?; 6192 Cum face [prepelița]? (verb, onomatopee).

Pentru textele 224-226 din AAF V există în chestionar întrebarea 5755 În care zile din săptămână nu e bine să faci anumite lucruri (1) să coşi, (2) să pleci la drum, (3) să zideşti etc.)? care reunește diferite zile oprite de la lucru.

În cadrul secțiunii Demoni, ființe fantastice sau cu puteri supranaturale, textele 228 Vâlfa, 229 și 230 Balaurul, 231 Șolomățul, 233 Vârcolacii, 234 Moroi, 235 Prigurici $^{8}$ etc. din AAF V sunt texte răspuns sau ad-uri la chestiunile 4237 mama pădurii; 4242 bălaur, pl., 5796 //solomonar//; ce se crede despre şolomonari?; 2456 Luna o mănâncă vârcolacii; 4240 ştimă la vite; 4233 pricolici (mort prefăcut în fiară) etc.

Și pentru texte ca 241 [Șarpele de casă], 242 Măsurăm laptele, 248 [comoara] din AAF V, fișele de anchetă au legătură cu ancheta pentru atlas sau poartă mențiunea ad: 6228 //şarpel/; şarpe de casă (ce se crede despre el?), pl.; 5663 strămurare; 4250 comoară. Cum se caută?

Studiul lui E. Petrovici (1939, p. 113-132) referitor la Obiceiuri - La sărbători, La naștere, La nuntă, la moarte şi înmormântare, precum și informațiile oferite despre ocupația ${ }^{9}$, locuința, portul sau hrana moților din zona Scărișoarei fructifică documentarea pe baza chestionarului ${ }^{10}$. Sărbătorile mari și sărbătorile de peste an, obiceiurile de Anul Nou, de Crăciun, perioada posturilor mari, obiceiurile de Arminden, Sânziene, Gherman, Pantelimon etc. se regăsesc în cuprinsul chestio-

\footnotetext{
${ }^{8}$ Textul în manuscris se poate vedea în 1.2. Foto ms., fila 15 din secțiunea de texte, ca ad 4233 pricolici (mort prefăcut în fiară) (prentru chestiunea 4 233, vezi ALR II s.n., vol. 3, h. 1314 Pricolici).

${ }^{9}$ Informații din jurnalul de anchetă sunt cuprinse și în ALR II. Introducere, p. 44 și urm.

${ }^{10}$ Rolul, importanța și complexitatea Chestionarului ALR II (și a chestionarului de probă) au fost evidențiate de noi în Adam 2019, 2021, Vlasin 2019, 2020, 2021.
} 
narului (vezi, spre exemplu, chestiunile 2 781-2 850; vezi foto ms., supra, 1.4.). De altfel, și simpla consultare a „Indicelui folkloric” din ALRT II (p. 341-344) indică prezența textelor pe aceste teme în multe alte puncte de anchetă din rețeaua ALR II. Obiceiurile la naștere apar în toate punctele de anchetă, acestea fiind documentate în chestionar prin întrebări ca: 2652 Ce se face cu copilul mic îndată după naştere?. Obiceiurile la nuntă sunt, de asemenea prezente în texte, fără excepție, fiind legate de întrebările 2 670-2 697 din chestionar. Același lucru este valabil pentru obiceiurile la înmormântare, chestiunile 2 698-2 713 (în special 2712 Care sunt obiceiurile la înmormântare?).

2.2. Următorul moment în timp în valorificarea textelor dialectale ${ }^{11}$ înregistrate în punctul 95 Scărişoara este reprezentat de publicarea în 1943 a Textelor dialectale. Suplement la Atlasul lingvistic român II (ALRT II), Sibiu-Leipzig, Muzeul Limbii Române-Otto Harrassowitz.

Dacă pentru textele publicate în 1939 în AAF V E. Petrovici recurge la o simplificare a transcrierii fonetice iniţiale ${ }^{12}$, transcriere pe care a utilizat-o, fără excepție, pentru toate textele culese în perioada anchetelor din 1935 și 1937, textele publicate în ALRT II, p. 48-64 sunt redactate păstrând, evident, transcrierea fonetică ce stă la baza anchetelor ALR (pentru facsimile, vezi supra, 1.5. Foto ms.).

Cele $25^{13}$ de texte din ALRT II sunt, în transcriere fonetică, texte publicate și în Folklor de la moții din Scărișoara, fie în secțiunea de texte propriu-zise (numerotate de la 1 la 252, în Petrovici 1939, p. 136-168), fie cuprinse în descrierea obiceiurilor, a ocupațiilor, a locuinței, a portului ori a hranei (Petrovici 1939, p. 111-132). Excepție fac textele Sărbători băbești (ALRT II, p. 50), Obiceiuri la mort (ALRT II, p. 62-63), Sărbători (ALRT II, p. 63) care prezintă unele diferențe (de redactare și/sau conținut) ori completări faţă de varianta din AAF V și ultima „Ciumelitură” (ALRT II, p. 64), care lipsește din AAF V.

În urma confruntării dintre manuscrisul textelor din localitățile și crângurile în care a fost efectuată ancheta și textele publicate în AAF V (atât textele numerotate de la 1 la 252, cât și cele cuprinse în studiul introductiv al materialului publicat în 1939, cu privire la diferite aspecte din viața locuitorilor (port, hrană, ocupații, obiceiuri etc.) și în ALRT II am constatat valorificarea aproape integrală a textelor notate pe teren. Excepție fac câteva strigături și câteva cimilituri cu conținut licențios, rămase inedite din motive evidente.

\footnotetext{
${ }^{11}$ Ar trebui, însă, să avem în vedere și publicarea ca MN a unor texte și fragmente de text în ALR II/I (1940). Este vorba despre chestiuni ca: 2692 mărul de la nuntă (ALR II/I/MN 82), 2711 năsălie (ALR II/I MN 86, Pe ce duceți mortul la groapă?); 2712 Care sunt obiceiurile la înmormântare? (ALR II/I MN 89 Răspuns la întrebarea: ce obiceiuri deosebite aveţi la înmormântare?); 2 798 Care sunt obiceiurile de Anul Nou? (ALR II/I MN 110, Răspuns la întrebarea: Ce obiceiuri mai aveti la Anul Nou?) etc., unde se fac de multe ori trimiteri la volumul de texte dialectale care va fi publicat trei ani mai târziu. Pentru conexiunea dintre textul dialectal și hărțile sau materialul necartografiat cu care acesta este în strânsă legătură, vezi Vlasin 2020, p. 156-157; Vlasin 2021.

12 Vezi descrierea transcrierii utilizate pentru textele din AAF V în Petrovici 1939, p. 133-134.

${ }^{13}$ Numărătoarea are în vedere titlurile sub care au fost cuprinse textele. Pentru textele intitulate Horă (ALRT II, p. 55-57, 58-59, 60-62), Strigătură (ALRT II, p. 55), texte publicate și în AAF V, numerotarea acestora este diferită (textele: 6-16; 17-21, 41; 56-64; respectiv 97-98).
} 


\section{Perspective în valorificarea unitară a textelor dialectale culese în ancheta din Scărișoara}

Proiectul accesibilizării fondului documentar ALRT II (vezi nota *), prin digitalizarea textelor publicate în 1943 vizează și valorificarea integrală a textelor din arhiva ALR II rămase inedite ${ }^{14}$.

Pentru materialul din punctul 95 Scărișoara demersul restitutiv va consta în transcrierea fonetică utilizată în timpul anchetei a textelor publicate de E. Petrovici în 1939 în AAF V, în transcriere simplificată. Materialul astfel rezultat va completa imaginea graiului din acest punct de anchetă.

Așa cum am constatat în cursul activității de identificare a textelor inedite din alte puncte de anchetă ale ALR II, și pentru ancheta din Scărișoara unele răspunsuri pe baza chestionarului pot fi redactate ca text - este vorba, în general, de întrebări care solicită un răspuns complex (despre aceste întrebări din chestionar vezi Vlasin 2020, p. 153-156; Vlasin 2021).

Prin acest demers, materialul cules de Emil Petrovici în Țara Moților într-un moment în care graiul deja începea să fie expus la influențe din alte zone își va dezvălui integral valoarea sa lingvistică.

\section{ABREVIERI BIBLIOGRAFICE. SIGLE}

AAF V = Anuarul Arhivei de Folklor V, publicat de Ion Mușlea, Monitorul Oficial și Imprimeriile Statului, Imprimeria Națională, București, 1939.

Adam 2019 = Gabriela Violeta Adam, Din arhiva Muzeului Limbii Române. Chestionarul anchetelor de probă ale Atlasului lingvistic român, în CSP IV, Cluj-Napoca, 2019, p. 37-51.

ALR I/I, II = Sever Pop, Atlasul lingvistic român. Partea I, vol. I. Părțile corpului omenesc și boalele lui, Cluj, 1938; vol. II. Familia, nașterea, botezul, copilăria, nunta moartea, Sibiu-Leipzig, 1942.

ALR II/I = Emil Petrovici, Atlasul lingvistic român. Partea II, vol. I. A. Corpul omenesc, boale (și termini înrudiți). B. Familia, nașterea, copilăria, nunta, moartea, viața religioasă, sărbători. C.Casa, acareturile, curte, focul, mobilierul, vase, scule, Sibiu-Leipzig, Muzeul Limbii Române-Otto Harrassowitz, 1940.

ALR II s.n. = Emil Petrovici, Atlasul lingvistic român. Partea a II-a, serie nouă. Redactor principal Ioan Pătruț, vol. I-VII, Editura Academiei Republicii Populare/Socialiste Române/România, București, 1956-1972.

ALR II. Introducere $=$ Emil Petrovici, Atlasul lingvistic român II. Introducere . Editat de Doina Grecu, I. Mării, Rodica Orza; coordonator: I. Mării, Cluj-Napoca, Universitatea din Cluj-Napoca - Institutul de Lingvistică şi Istorie Literară, 1988.

ALRT II = Emil Petrovici, Texte dialectale culese de... Suplement la Atlasul lingvistic român II (ALRT II), Sibiu-Leipzig, Muzeul Limbii Române-Otto Harrassowitz, 1943.

Chestionarul ALR II = Chestionarul Atlasului lingvistic român II. Elaborat, în cadrul Muzeului Limbii Române, sub conducerea lui Sextil Pușcariu, de Emil Petrovici și editat, în cadrul Institutului de Lingvistică și Istorie Literară, de Doina Grecu, I. Mării, Rodica Orza, S. Vlad. Coordonator: I. Mării, Cluj-Napoca, Universitatea din Cluj-Napoca-Institutul de Lingvistică şi Istorie Literară, 1988.

\footnotetext{
${ }^{14}$ E. Petrovici menționează că aceste texte, notate în puncte de anchetă în care au fost găsiți buni povestitori, de la care s-au putut aduna texte mai lungi sunt păstrate în arhiva atlasului (vezi ALRT II, Prefață, p. VI).
} 
CSP $=$ „Caietele Sextil Pușcariu”. Actele Conferinței Internaționale „Zilele «Sextil Pușcariu»”, Cluj-Napoca, I, 2013 și urm.

Cuceu \& Cuceu 2012 = Emil Petrovici, Cercetări etnologice și dialectologice în Transilvania și Banat, editori Ion Cuceu și Maria Cuceu, Editura Fundației pentru Studii Europene, Cluj-Napoca, 2012.

Nevaci, Floarea, Farcaș 2021 = Manuela Nevaci, Irina Floarea, Ioan-Mircea Farcaș (editori), Ex Oriente lux. In honorem Nicolae Saramandu, Alessandria, Edizioni dell’Orso, 2021, («La colonna infinita»14).

Frâncu, Candrea 1888 = T. Frâncu, G. Candrea, Românii în Munții Apuseni (moții), București, Tipografia modernă, 1888.

Papahagi 1925-1926 = Tache Papahagi, Cercetări în Munţii Apuseni, în „Grai și suflet”, revista Institutului de Filologie și Folclor, publicată de Ovid Densusianu, II, București, Atelierele Socec \& Co., 1925-1926, p. 22-89.

Petrovici 1939 = E. Petrovici, Folklor de la moții din Scărișoara, în AAF V, 1939, p. 111-175.

Vlasin 2019 = Veronica Ana Vlasin, Din arhiva Muzeului Limbii Române. Ancheta de probă din Săliște (jud. Sibiu), în CSP IV, Cluj-Napoca, 2019, p. 288-298.

Vlasin $2020=$ ALRT II - de la anchetă la redactare, în „Dacoromania”, serie nouă, XXV, nr. 2, Cluj-Napoca, p. 149-160.

Vlasin 2021 = Veronica Ana Vlasin, ALRT II - tipologia textelor și importanța chestionarului ALR II în culegerea de texte, în Nevaci, Floarea, Farcaș 2021, p. 1117-1124.

\title{
THE DIALECTAL INQUIRY FOR ALR II IN SCĂRIȘOARA. WAYS OF VALORIZING THE DIALECTAL TEXTS
}

\section{(Abstract)}

The paper approaches the information on the dialectal texts collected in Scărișoara during the inquiries for The Romanian Linguistic Atlas II in 1935 and 1937. The material stored in the atlas archive comprises a section that Emil Petrovici based on his ethno-folcloric study and collection of texts published in 1939, in ,Anuarul arhivei de folclor" V, and the part edited for his collection of dialectal texts published in 1943 (ALRT II).

The paper presents the categories of files in the archive, compares the manuscripts with the published material, underlining the similarities with the dialectal texts collected in other cartographic points of ALR II network and proposes a unitary approach by restoring the texts published in 1939, in a simplified version, back to their original phonetic transcription, in order to ofer a complete linguistic view on the material collected in that area.

Cuvinte-cheie: anchetă dialectală, anchetă etno-folclorică, texte dialectale, Atlasul lingvistic român II, Scărișoara.

Keywords: dialectal inquiry, ethno-folkloric inquiry, dialectal texts, the Romanian Linguistic Atlas II, Scărișoara.

\author{
Institutul de Lingvistică și Istorie Literară \\ „Sextil Pușcariu” al Academiei Române \\ Cluj-Napoca, str. Emil Racoviță, 21 \\ veronica.vlasin@academia-cj.ro \\ gabriela.adam@academia-cj.ro
}

